\title{
Article \\ Perceptions and Resistance to Accept Smart Clothing: Moderating Effect of Consumer Innovativeness
}

\author{
Naan Ju ${ }^{1}\left(\right.$ ) and Kyu-Hye Lee ${ }^{2, *(1)}$ \\ 1 Research Institute of Industrial Science, Hanyang University, Seoul 04763, Korea; naan_ju@hanyang.ac.kr \\ 2 Human-Tech Convergence Program, Department of Clothing and Textiles, Hanyang University, \\ Seoul 04763, Korea \\ * Correspondence: khlee@hanyang.ac.kr
}

Citation: Ju, N.; Lee, K.-H.

Perceptions and Resistance to Accept Smart Clothing: Moderating Effect of Consumer Innovativeness. Appl. Sci. 2021, 11, 3211. https://doi.org/ 10.3390/app11073211

Academic Editor: Akram Alomainy

Received: 17 March 2021

Accepted: 31 March 2021

Published: 3 April 2021

Publisher's Note: MDPI stays neutral with regard to jurisdictional claims in published maps and institutional affiliations.

Copyright: (c) 2021 by the authors. Licensee MDPI, Basel, Switzerland. This article is an open access article distributed under the terms and conditions of the Creative Commons Attribution (CC BY) license (https:// creativecommons.org/licenses/by/ $4.0 /)$.

\begin{abstract}
Despite positive expectations from different organizations, smart clothing has not spread to the public. This study surveyed 320 adults to identify multiple obstacles arising from the adoption of smart clothing. As a result, perceived risks and unavailability of smart clothes, which are innovative products, have increased innovation resistance to smart clothes. On the other hand, smart clothing improvement expectations have been shown to lower innovation resistance to smart clothing. This suggests that interest and goodwill in a particular technology or function have significant impact on consumers' willingness to accept it. Next, we validated the moderating effect of consumer characteristics in the relationship between innovative characteristics of smart clothing and innovation resistance. As a result, consumers' fashion innovativeness has been shown to play a role in strengthening innovation resistance to smart clothing that is affordable. It can be inferred that the more fashion-conscious consumers are, the more burdened they are to continue to purchase relatively expensive smart clothes as the trend changes. In conclusion, to spread smart clothing, it is necessary to decrease the consumers' perceived risk and improve the performance, durability, and availability of smart clothing.
\end{abstract}

Keywords: innovation resistance; smart clothing; moderating effect; consumer innovativeness

\section{Introduction}

Recently, global attention has been focused on the Internet of Things (IoT), which allows objects to collect, share, and interact with information as if they were living organisms by giving them sensors and communication functions. Wearable technologies and devices that combine fashion and IoT are also emerging as major issues in the fashion industry. Although detailed figures vary from institution to institution, expectations for the wearable market are very positive as IoT technology quickly penetrates lifestyle. Recently, due to the development of new material technologies such as conductive fiber and textile sensors, attempts have been made to implement electronic substrates or make clothing into a single computer.

Gartner [1] predicts that smart clothing shipments among many wearable devices will reach 19.9 million by 2022 despite only 5.65 million shipments in 2018. However, the actual market penetration rate of many newly released wearable devices is not very high, and the purchase and actual usage rate of wearable devices has not met expectations. This contrasts with the high consumer awareness of wearable devices, meaning that wearable devices are mainly only used by early adopters and are not spreading to the public. In this study, we aim to contribute to the spread of smart clothing by using innovation resistance models to reveal various obstacles in the process of smart clothing adoption and by studying consumer groups that refuse to adopt smart clothing. Referring to the results of this study, if products are improved as consumers wish at the current level of technology and functionality, wearable devices could be a new growth engine for fashion brands and technology companies. 


\section{Literature Review}

\subsection{Smart Clothing}

Smart clothing is a type of wearable device, which can be defined as electronic devices with built-in sensors that can receive data about wearers or their surroundings. These devices work wirelessly or through other devices such as smartphones and tablets. Wearable devices are subdivided into applications or forms, depending on the organization. The IEC (International Electrotechnical Commission), an organization that adjusts national standards in electricity, electronics, telecommunications, and nuclear power, defines electronic fibers as a category of wearable smart devices [2]. Gartner, an information technology research and advisory company in the United States, also classifies smart clothing as a type of wearable smart device in consideration of the location where it is worn and the use and shape of the device. In Korea, smart clothing is defined as clothing that combines IT technology with cutting-edge textiles, materials, and technologies, and is a textile product that applies a detection and response system to the stimulus of the surrounding environment or human body [3], or as a new concept of high-function, high-performance, multi-functional clothing that can express various functions complexly or express new functions while maintaining the emotional and functional properties inherent in clothing [4]. Such smart clothing is used together with terms such as wearable computers, digital clothing, and intelligent clothing [5].

According to Cientifica [6], smart clothing has now entered the fourth generation. Smart clothing has evolved from the initial form of attaching electronic devices to clothes to the second-generation smart clothing with built-in sensors and to the third-generation with sensor functions in the fabric itself. Fourth-generation smart clothing, which is currently being developed, intends to use devices that are not noticeable because they are as natural as possible. Experts predict that smart clothing growth will be the highest among wearable smart devices in the future [7] based on a sluggish fitness tracker, excessive supply of smart watches, and global companies such as Google, Adidas, and Under Armour's participation in the market.

According to GMI APC's wearable technology survey, only $20 \%$ of respondents said they knew about smart clothing [8], indicating that consumers' perceptions of electronic textiles or smart clothing are not as high as other wearable products. Additionally, according to NPD's research on the performance required for smart clothing, more than half of the respondents are aware of the stain-resistant and waterproof properties of smart clothing and are interested in sweat-absorbing, quick-drying, UV protection, and cooling fabrics [9]. This indicates that many consumers still confuse functional clothing and smart clothing. Smart clothing is a concept that is differentiated from existing functional clothing. While clothing designed from the time of manufacture for a certain purpose is called functional clothing, there is a difference in that smart clothing performs a certain function by determining the clothing itself for the user [10].

Prior studies on wearable devices and smart clothing have focused mainly on functional aspects such as usability, ease of use, and convenience based on Davis' Technology Acceptance Models (TAM). However, existing studies have not shown why smart clothing is slow to spread among consumers, contrary to current expectations. Furthermore, inconsistent research results have made it difficult to obtain sufficient answers to the acceptance and resistance of smart clothing. In this study, we define smart clothing as clothing that can interact with wearers, surroundings or situations, clothing that can detect and respond to human stimuli, and identify factors that affect innovation resistance to smart clothing.

\subsection{Innovation Resistance}

Innovation resistance, which means rejection or resistance to innovation, may be defined as a negative response to innovation and changes associated with innovation, although it depends on scholars. Until now, many studies have identified factors that influence the acceptance and spread of innovation by viewing innovation as positive and beneficial. However, there is a lack of research on innovation resistance, one reason 
why many innovations fail to be accepted. In many cases, changes caused by innovation break the psychological balance of consumers, and consumers either make psychological rebalancing or resist changes to address this imbalance. The fact that about $47 \%$ of leading companies that released innovative products fail to spread the market and are excluded from the competitive market [11] shows the importance of innovation resistance. According to Diamond [12], resistance to change is a defensive and adaptive propensity intended to protect the present state, and thus resistance to innovation is a normal response to finding psychological stability. Gourville [11] argued that in accepting innovation, consumers are required not only to bear the cost of economic transformation but also the cost of psychological transformation, resulting in a negative attitude toward accepting innovation. Similarly, Ellen, Bearden, and Sharma [13] viewed the resistance to change as an evaluation response to maintain the present state and view the resistance to innovation as attitudes and preferences. Since even innovators may have rejecting or negative views in the process of purchasing, processing, and using that, Ram [14] defined innovation resistance as an independent attitude, not an opposite concept of acceptance or diffusion to innovation. Research on innovation resistance has been conducted in various ways, including the form of resistance [15], type of resistance [16,17], innovation resistance model [14], scale development [18], and factors affecting resistance [14,19,20].

Ram [14] proposed an innovation resistance model by overcoming the limitations of existing innovation diffusion theory and incorporating several types of resistance factors, including innovation characteristics, consumer characteristics, propagation mechanisms, and environmental factors. The innovation resistance factors presented in Ram's innovation resistance model include (1) innovation characteristics, (2) consumer characteristics, and (3) propagation mechanisms, and innovation characteristics affect innovation resistance, suggesting consumer-dependent and consumer-independent factors. However, propagation mechanisms need to be studied separately because they are obstacles to the diffusion process of innovation and are not resistors in the acceptance process [21]. In this study, we set innovation characteristics as independent variables, innovation resistance as dependent variables based on Ram's innovation resistance mode [14]. Additionally, to identify differences in consumers' innovativeness in this process, the fashion innovativeness and technological innovativeness of consumers are set as moderate variables.

\subsection{Factors Affecting the Resistance to Innovation}

\subsubsection{Perceived Compatibility}

Compatibility is a variable indicating how much the innovation is consistent with the value, past experience, and consumer needs [14,22]. This means not only the consumer's existing values, but also the traditional or cultural values, and the degree to which they are consistent with the consumer's current lifestyle. Rogers [23] noted that the uncertainty of potential inmates is reduced, especially when an idea or product is highly compatible because people give more meaning to and think more intimately about new ideas or products that they think are highly compatible.

According to Nam and Lee [24], factors affecting the acceptance of smart clothing include design and consistency with wearer images. Meanwhile, Cho et al. [25] revealed that smart clothing preferences also differ depending on lifestyle types. Ju [26] argues that consumers positively evaluated smart clothing when they perceived that the function of smart clothing was suitable for clothing, such as design flexibility. On the other hand, consumers resist smart clothing if they perceive the function of smart clothing is not suitable for clothing or that there is a limit when it is implemented as clothing. For example, Consumers welcomed useful features that were implemented in clothing, such as changes in patterns and colors. However, consumer's responses were negative for clothes when they were equipped with functions that can be measured more accurately with smartphones or smartwatches, such as heart rate checks and activity tracking.

In the study of product extensions, similarity-related studies are divided into two categories: attribute similarity and concept similarity. Similarity of product properties 
means similarity in the function, physical characteristics, use conditions, technologies required to manufacture the product, etc. [27,28]. Ma, Won, and Park [29] said that for sports wearable devices, efforts to consider functional fit and design fit with conventional sportswear during the manufacturing and planning stages would be an important way to reduce consumer innovation resistance. Thus:

Hypothesis 1. Perceived compatibility of smart clothing negatively influences innovation resistance.

\subsubsection{Expectations of Future Product Capabilities}

In the case of high-tech industries, the development of new technologies and products tends to be rapid. Additionally, the introduction of a new product due to these technological changes and consumers' expectations and concerns related to this can be an important cause of consumers' regret over the purchase of old products and hesitation about the purchase of new products [30]. Recently, with the development of state-of-the-art technologies, this uncertainty has been aggravated by the acceleration of the launch of new products with more advanced features. According to Cheon [31], about $40 \%$ of buyers of wrist-worn wearable devices for fitness tracking do not use the product within six months of purchase. This is because consumers expect the emergence of smart textile wearables that are more "easy to wear". Thus:

Hypothesis 2. Expectations of future product capabilities positively influences innovation resistance.

\subsubsection{Perceived Unavailability}

Availability refers to the degree to which a service or product can be used when expected [32]. The service or product must be available when the user wants to use it, and when the availability decreases, the consumer's intention to use the product or service decreases [33]. In the case of smart clothing, the advantage is that it can detect and respond to the surrounding environment or situation and stimuli of the human body $24 \mathrm{~h}$ a day, 365 days a year, just by wearing it. This advantage is related to the concept of availability, which is defined as the degree that the user can always use the desired function without interruption when they want it. According to Ju [26], smart clothes must be washed frequently and are sensitive to seasonal factors and trends due to the characteristics of clothing. Therefore, consumers are concerned about the situation in which they cannot use the product due to laundry or seasonal or fashion changes. They also showed a negative reaction to purchasing multiple products. Therefore, it can be expected that the availability perceived by users will also affect the innovation resistance to smart clothing. Thus:

Hypothesis 3. Perceived unavailability of smart clothing positively influences innovation resistance.

\subsubsection{Perceived Risk}

Ram [14] argued that innovation resistance arises according to the risks involved in innovation, and that the higher the risk, the higher the innovation resistance. Until now, consumers' perception of risk has been measured in various dimensions [34]. For many consumers, the judgment they want to trust mostly refers to safety standards [35]. For other consumers, this confidence can be extended to include judgments about ethical considerations as to whether a product should be available in the marketplace. Smart clothing is still early in development, and there are no safety standards related to the manufacture and sale of smart and e-textiles and smart clothing. Under these circumstances, consumers are expected to perceive several risks to smart clothing, and consumers' perceived risks to smart clothing are expected to have an impact on determining whether smart clothing is accepted or not.

In this study, performance risks and physical concerns about the risks that products can pose to health or safety, which are perceived by many consumers in relation to smart 
clothing [26], are among various types of risks. Physical risk arises from concerns about the risks a product may pose to health or safety [36], and many studies on consumer resistance have demonstrated that the higher the physical risk, the higher the consumer's resistance $[37,38]$. Next, functional risks stem from concerns about whether the product will perform as expected [36,39]. Szmigin and Foxall [15] empirically verified that the higher the functional risk, the higher the resistance to innovation. Thus:

Hypothesis 4. Perceived risk of smart clothing positively influences innovation resistance.

\subsubsection{Perceived Relative Advantages}

Ram [14] proposed the proposition that the higher the relative advantage of innovation perceived by consumers, the lower the consumer's resistance to innovation. In many subsequent studies, it was verified that the higher the relative advantage, the lower the resistance to innovation. Relative advantage is a variable that represents the benefits of life becoming useful or convenient as consumers adopt innovations, which can appear in the form of a higher value at the same or lower cost compared to the previous one. According to Shiffman and Kanuk [40], lower benefits of innovation compared to conventional products lead to less attractiveness and consumer resistance. In other words, a relative advantage is essential for an innovation product to be accepted by consumers, and if a new product is not as good as the existing product or is less attractive than the current product, there can be resistance to innovation. Meanwhile, the TAM presents "perceived usefulness" instead of "relative advantage" [41]. According to some prior studies, perceived usefulness has a positive effect on attitudes and intended use of smart clothing and fashion products $[42,43]$. On the other hand, Chae, Cho, and Lee [44] showed different findings among prior studies, saying that perceived usefulness does not directly affect the acceptance of smart clothing. Thus:

Hypothesis 5. Perceived risk of smart clothing negatively influences innovation resistance.

\subsubsection{Perceived Monetary Value}

According to Morgan Stanley [45], consumers do not buy smart wearable devices due to them being (1) unnecessary, (2) expensive, (3) inconvenient, and (4) design/function dissatisfaction. In other words, high prices pose an obstacle to accepting new products. In fact, achieving the purchase objective associated with the purchase behavior involves expenses, which are directly linked to the consumer purchase behavior. Cost rationality refers to the extent to which the user recognizes that the level of economic costs that the user feels for a particular product is reasonable or appropriate [46]. Thus, cost rationality is the basis for assessing a product when consumers use a product or service [47], which negatively affects their choice if they feel that they have invested more than they need [48]. Thus:

Hypothesis 6. Perceived monetary value of smart clothing negatively influences innovation resistance.

\subsubsection{Consumer Characteristics}

Identifying individual characteristics is an important prerequisite for consumeroriented service development and strategy setting, which is important for new product development and market creation. Consumer innovation propensity is an indication of how easily and quickly consumers embrace new things, and prior studies on consumer innovation $[23,49,50]$ have identified innovation as related to personality, a characteristic that all consumers have, where degree differences exist over a lifetime. Midgley and Dowling [50] understood innovation as a concept of innate personality and innate innovation. They also explained that innovativeness, which is sensitive to new ideas, has a significant impact on consumers' various decision-making and behaviors. On the other hand, Goldsmith and Hofacker [51] explained that innovation is desirable to be measured 
in relation to a particular domain or product because consumer-related behaviors mostly occur in a domain or context-specific manner. Thus, to increase predictive power in this work, we included domain-specific innovativeness that directly related to innovation as variables. Since smart clothing is a fashion garment that incorporates electronic technology, consumers' fashion innovativeness and technological innovativeness are expected to affect their acceptance. Therefore, based on the results of the prior study, this study aimed to examine the impact of fashion innovativeness and technological innovativeness on attitudes and purchase intentions for smart clothing.

Innovation in fashion products means the interest and importance of consumers in fashion [52], and groups with high interest in fashion adopt new fashion products more quickly than those with low interest in fashion. Currently, fashion refers to the spread of certain styles, colors, and symbolic meanings among individuals in society, and thus fashion innovativeness plays an important role in the acceptance of new fashion products. According to Kang and Jin [42], the fashion innovativeness of consumers influenced the perceived usefulness of smart clothing. This is because those who quickly accept the fashion of clothing find it useful to attach various devices to clothing, which is the object of their interest and innovation, to replace multiple devices. Meanwhile, Noh and Park [43] revealed that their intention to accept smart clothing would differ depending on an individual's fashion innovativeness and information innovativeness.

Agarwal and Prasad [53] report that people with high innovation in information technology have higher intentions for the use of new information technologies or systems by forming more positive perceptions of relative benefits, ease of use, compatibility, etc. According to Kang and Jin [43], technological innovation has influenced the ease of use of smart wear, which means that those who quickly accept high-tech products are accustomed to manipulating the device, so it is easy to operate the device attached to the smart clothing. Park and Noh [54] also found that technological innovation has a significant positive effect on purchase intention. Through this, it was found that it is necessary to emphasize that smart clothing is an innovative technology product based on IT technology to form the consumer's purchase intention for smart clothing. Thus:

Hypothesis 7. Consumers' fashion innovation negatively influences the relationship between the properties of smart clothing and innovation resistance.

Hypothesis 8. Consumers' technology innovation negatively influences the relationship between the properties of smart clothing and innovation resistance.

\section{Methods}

\subsection{Research Model and Measurement}

Based on the innovation resistance model of Ram [14], a representative theory describing the innovation resistance of new products, we distinguished the key variables affecting resistance to smart clothing into perceived innovation characteristics and consumer characteristics. In addition to the direct effect of innovation characteristics on innovation resistance to smart clothing, we also considered the moderating role of consumers' fashion innovativeness and technological innovativeness. Based on the review of the literature, the following hypotheses resulted (see Figure 1). 


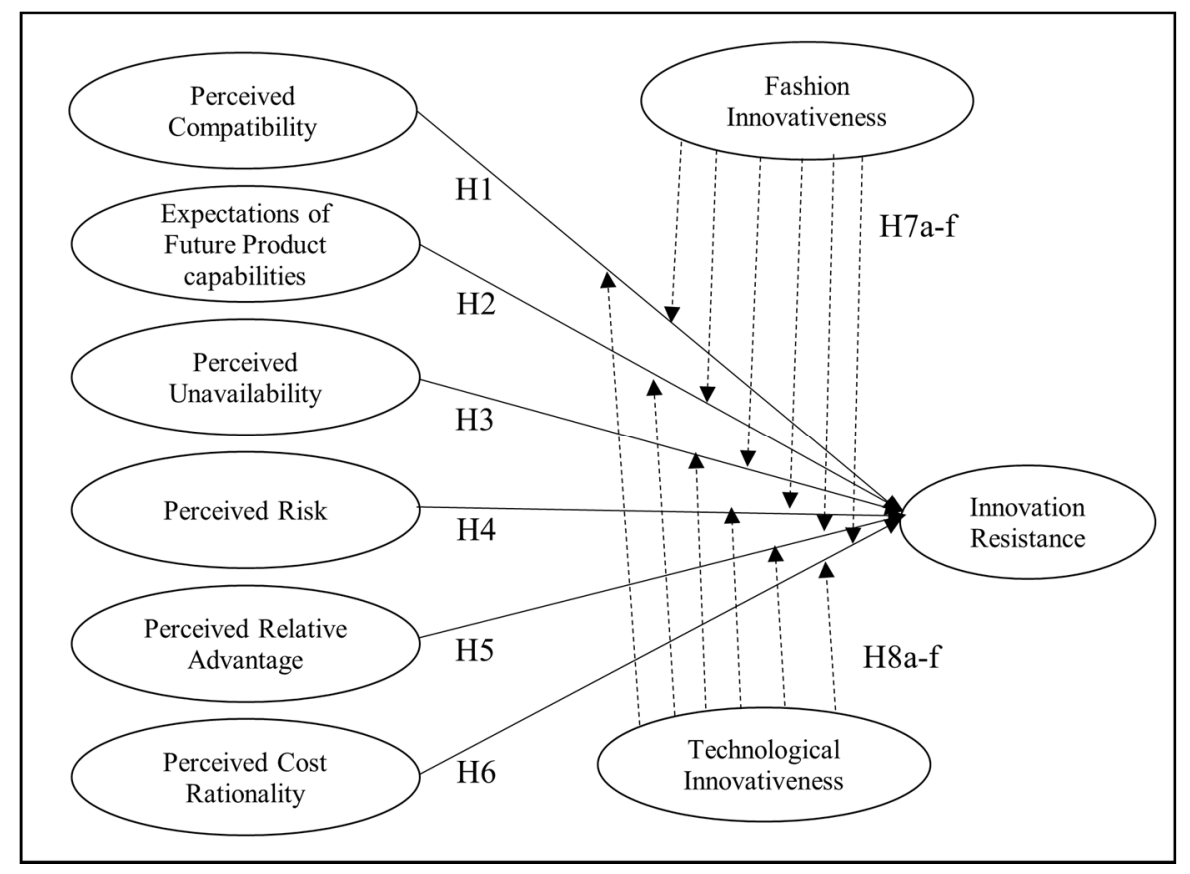

Figure 1. Research model.

\subsection{Data Collection}

Since smart clothing has not yet been commercialized at the initial stage of its release, it is difficult to conduct a survey for users. In addition, since the purpose of this study is to reveal the factors of resistance to innovation of smart clothing targeting general consumers, this study conducted a survey after presenting definitions of smart clothing targeting general consumers. To test the research hypotheses, a web-based survey was employed to collect data. The survey was conducted by a professional panel. Among the potential participants who received an invitation by e-mail from a panel provider, only consumers who had shopping experience of smart clothing were asked to answer questions. Upon accessing the survey site, participants were first asked to read a brief description of the study and then provided explanations and examples of smart clothing. Participants were then asked to answer questions that measure major research variables. A total of 320 valid responses were included in the final data analysis.

\subsection{Measurement}

This study included the perceived compatibility, expectations of future product, perceived unavailability, perceived risk, perceived relative advantage, and perceived monetary value to validate the presented hypotheses, while moderators included consumers' fashion innovativeness and technological innovativeness. All the items were reported on a 5-point Likert scale where 1 and 5 were denoted as "Strongly Disagree" and "Strongly Agree" (Table 1). 
Table 1. Exploratory Factor Analyses (EFA) results with final measurement items.

\begin{tabular}{|c|c|c|c|}
\hline Variables & Items & $\begin{array}{l}\text { Factor } \\
\text { Loadings }\end{array}$ & Cronbach's $\alpha$ \\
\hline $\begin{array}{l}\text { Perceived } \\
\text { Compatibility }\end{array}$ & $\begin{array}{l}\text { Smart Clothing design fits well with my other clothes. } \\
\text { Smart clothing functions well with clothing } \\
\text { Smart Clothing meets my needs better than my other clothes. } \\
\text { Smart Clothing matches my lifestyle. } \\
\text { Smart clothing fits well with the smart } \\
\text { clothing image I was thinking of. } \\
\text { Smart clothing is necessary. }\end{array}$ & $\begin{array}{l}0.816 \\
0.749 \\
0.744 \\
0.742 \\
0.712 \\
0.612\end{array}$ & 0.882 \\
\hline $\begin{array}{l}\text { Expectations of future } \\
\text { product capabilities }\end{array}$ & $\begin{array}{l}\text { I look forward to the release of } \\
\text { more convenient smart clothing in the future. } \\
\text { I look forward to the release of more } \\
\text { versatile smart clothing in the future. } \\
\text { I look forward to the release of } \\
\text { safer smart clothing in the future. }\end{array}$ & $\begin{array}{l}0.850 \\
0.835 \\
0.812\end{array}$ & 0.916 \\
\hline $\begin{array}{l}\text { Perceived } \\
\text { Unavailability }\end{array}$ & $\begin{array}{l}\text { Smart clothing does not seem to } \\
\text { be always available when I want it. } \\
\text { Smart clothing does not seem to } \\
\text { be always available when I need it } 0 \text {. } \\
\text { It seems that the functions of smart clothing will not be able to } \\
\text { be used stably and seamlessly. }\end{array}$ & $\begin{array}{l}0.861 \\
0.842 \\
0.572\end{array}$ & 0.779 \\
\hline Perceived Risk & $\begin{array}{l}\text { I think smart clothes will break down soon. } \\
\text { I think the function of smart clothes will work improperly. }\end{array}$ & $\begin{array}{l}0.811 \\
0.720\end{array}$ & 0.695 \\
\hline $\begin{array}{l}\text { Perceived Relative } \\
\text { Advantage }\end{array}$ & $\begin{array}{l}\text { Smart clothing is useful. } \\
\text { Smart clothing is more functional than other clothes. } \\
\text { Smart clothing makes my life more comfortable. } \\
\text { Using smart clothing takes less time and effort to accomplish } \\
\text { what I want to do than using other device. } \\
\text { Smart clothing is more convenient than other clothes. }\end{array}$ & $\begin{array}{l}0.653 \\
0.636 \\
0.602 \\
0.549\end{array}$ & 0.830 \\
\hline $\begin{array}{l}\text { Perceived } \\
\text { Monetary Value }\end{array}$ & $\begin{array}{l}\text { The price of smart clothing is affordable. } \\
\text { The price of smart clothing is reasonable. } \\
\text { The price of smart clothing is not burdensome to buy. } \\
\text { Smart clothing has high performance for the price. }\end{array}$ & $\begin{array}{l}0.872 \\
0.871 \\
0.581 \\
0.539\end{array}$ & 0.743 \\
\hline $\begin{array}{l}\text { Fashion } \\
\text { Innovativeness }\end{array}$ & $\begin{array}{l}\text { I purchase as soon as possible } \\
\text { when I hear the latest fashion information. } \\
\text { I always try to dress in a new way. } \\
\text { I am more interested in what is going to be popular in the } \\
\text { future than what is in fashion now. } \\
\text { I am sensitive to the latest fashion. } \\
\text { I enjoy shopping in stores with unique fashion items. } \\
\text { If I find a new store (brand), I will stop by. }\end{array}$ & $\begin{array}{l}0.846 \\
0.819 \\
0.815 \\
0.812 \\
0.798 \\
0.725\end{array}$ & 0.906 \\
\hline $\begin{array}{l}\text { Technological } \\
\text { Innovativeness }\end{array}$ & $\begin{array}{l}\text { I do not spare money for the products or services I need. } \\
\text { I am interested in new technologies or trends. } \\
\text { I am always interested in seeing if there is anything } \\
\text { better than the one I currently use. } \\
\text { I do not willingly purchase new products or services. (R) } \\
\text { I actively purchase or use new products or services. }\end{array}$ & $\begin{array}{c}0.666 \\
0.664 \\
0.658 \\
-0.637 \\
0.609\end{array}$ & 0.824 \\
\hline Innovation Resistance & $\begin{array}{l}\text { I have a negative opinion about smart clothing. } \\
\text { I feel dissatisfied with the use of smart clothing. } \\
\text { I will refuse even if someone recommends using smart clothing. } \\
\text { I am willing to oppose the use of smart clothing. } \\
\text { I am not willing to recommend using smart clothing. } \\
\text { I have something to criticize about using smart clothes. } \\
\text { I think that smart clothing is unnecessary. } \\
\text { I feel reluctant to use smart clothing. } \\
\text { There is no big benefit for me to use smart clothing. }\end{array}$ & $\begin{array}{l}0.841 \\
0.821 \\
0.781 \\
0.778 \\
0.749 \\
0.729 \\
0.710 \\
0.645 \\
0.562\end{array}$ & 0.919 \\
\hline
\end{tabular}




\subsubsection{Perceived Compatibility}

In this study, the compatibility of smart clothing is defined to the extent that it matches the lifestyle of the individual, the clothes he or she has, the current needs, the social image, and the functions provided by smart clothing. The questionnaire of compatibility is adapted and supplemented to this study, referring to the studies of Ma, Won, and Park [29] and Ju [26]. The measurement for compatibility consisted of five questions: "Smart Clothing matches my lifestyle", "Smart Clothing design fits well with my other clothes", "Smart clothing fits well with the smart clothing image I was thinking of", "Smart clothing functions well with clothing", and "Smart Clothing meets my needs better than my other clothes".

\subsubsection{Expectations of Future Product Capabilities}

According to Holak et al. [55], the higher the consumer expectation that better innovation will emerge soon, the higher the resistance to innovation. In this study, the expectation of improved innovation is defined as the expectation of consumers for the emergence of smart clothing with improved safety, functionality, and convenience. In this study, we used a modified and supplemented questionnaire by referring to the studies of Ram [14] and Yoo and Lee [56]. The measurements used in this study consisted of three questions: "I look forward to the release of more convenient smart clothing in the future", "I look forward to the release of more versatile smart clothing in the future", and "I look forward to the release of safer smart clothing in the future".

\subsubsection{Perceived Unavailability}

In this study, the perceived unavailability is defined as the extent that users believe that they cannot use products or services when they want and that their function performance is unstable. The measurement of product unavailability was used by Jo et al. [57] by modifying the questionnaire used to fit this study. The three questions used in the measurement consisted of "Smart clothing does not seem to be always available when I want it", "It seems that the functions of smart clothing will not be able to be used stably and seamlessly", and "Smart clothing does not seem to be always available when I need it".

\subsubsection{Perceived Risk}

In this work, perceived risks are defined as those perceived by consumers in relation to the acceptance of smart clothing, such as financial, functional, psychological, and social, and the measurement questions are modified and supplemented by the studies of Ram [14] and Yoo and Lee [56]. The questionnaire consisted of four questions: "I think the function of smart clothes will work improperly", "I think smart clothes will break down soon", "Wearing smart clothing is unlikely to be good for my health", and "Personal information is likely to be infringed by wearing smart clothing".

\subsubsection{Perceived Relative Advantage}

In this study, the relative advantages were defined to the extent that they perceived that smart clothing would provide improved benefits to respondents. The questionnaire for measuring relative advantage was modified to fit this study based on the studies of Ram [14] and Rogers [23]. Relative advantage was measured in a total of six questions, such as, "Smart clothing makes my life more comfortable", "Smart clothing is more functional than other clothes", "Smart clothing is more convenient than other clothes", "Smart clothing is useful", "Using smart clothing takes less time and effort to accomplish what I want to do than using other device", and "Smart clothing is necessary".

\subsubsection{Perceived Monetary Value}

In this study, the rationality of cost is defined to the extent that users feel satisfaction compared to the cost of purchasing and using smart clothing. To measure cost rationality, the scale used by Voss et al. [58] was modified and used for this study. The questions used 
in the measurement consisted of four questions: "The price of smart clothing is reasonable", "The price of smart clothing is affordable", "The price of smart clothing is not burdensome to buy", and "Smart clothing has high performance for the price".

\subsubsection{Fashion Innovativeness}

In this study, fashion innovativeness was defined as the degree of personal acceptance of fashionable products and new fashionable styles were measured using six items among the items used in the study of Kim and Rhee [59]. The measurement questions are composed of "If I find a new store (brand), I will stop by", "I always try to dress in a new way", "I am sensitive to the latest fashion", "I purchase as soon as possible when I hear the latest fashion information", "I am more interested in what is going to be popular in the future than what is in fashion now", and "I enjoy shopping in stores with unique fashion items".

\subsubsection{Technological Innovativeness}

In this work, we define technological innovativeness as an individual's tendency to accept new technologies. To measure acceptance and purchasing power for new technologies, the questions developed by Agarwal and Prasad [53] were modified to fit this study and used. The questions used to measure individual technological innovativeness consisted of five questions: "I am interested in new technologies or trends", "I actively purchase or use new products or services", "I am always interested in seeing if there is anything better than the one I currently use", "I don't spare money for the products or services I need", and "I do not willingly purchase new products or services".

\subsubsection{Innovation Resistance}

In this study, innovation resistance was defined as negative attitudes and behaviors of consumers toward innovative products and was measured by manipulating them as critical thinking, refusal to use, objection, indifference, and fear-based on previous research. As for the items used for measurement, nine items were extracted from the scales used in the research of Yoo and Lee [56] and Ryu [18]. The questions used to measure innovation resistance consisted of nine questions: "I feel reluctant to use smart clothing", "I am willing to oppose the use of smart clothing", "I feel dissatisfied with the use of smart clothing", "I have something to criticize about using smart clothes", "I think that smart clothing is unnecessary", "There is no big benefit for me to use smart clothing", "I have a negative opinion about smart clothes", "I will refuse even if someone recommends using smart clothing", and "I am not willing to recommend using smart clothing".

This section may be divided by subheadings. It should provide a concise and precise description of the experimental results, their interpretation, and the experimental conclusions that can be drawn.

\section{Results}

The average age of the respondents was 43.2 years old, and ranged from 19 to 69 and 60.6 percent were male. Only $5.3 \%$ of respondents said that they had purchased smart clothing. In the question about the appropriate price of smart clothing, $19.1 \%$ of respondents said that the price of smart clothing should be the same as or similar to regular clothing, and $41.2 \%$ of respondents said that it can be expensive from 1.5 to 2 times.

\subsection{Validity and Reliability Analysis}

SPSS Statistics were used to analyze the validity and reliability of this study and to verify the hypothesis. An exploratory factor analysis was conducted to confirm the validity of the measurement. Factors were extracted using principal component analysis and the Varimax method. Only factors with an eigenvalue of 1 or higher were selected, and only items with a factor loading of 0.5 or higher were selected for each factor. As a result of the exploratory factor analysis, as shown in the following Table 1, nine factors including compatibility, expectations of future product capabilities, unavailability, perceived risk, 
relative advantage, cost rationality, fashion innovativeness, technological innovativeness, and resistance to innovation was confirmed. All the variables' Cronbach's alpha values were above 0.6 , confirming the reliability.

\subsection{Correlation Analysis}

Prior to the hypothesis validation, correlation analysis was conducted to determine the relevance between variables. As shown in Table 2, correlations between variables have been shown to be appropriate overall.

Table 2. Mean, standard deviation, and correlation.

\begin{tabular}{|c|c|c|c|c|c|c|c|c|c|c|c|c|c|}
\hline Variables & Mean & S.D. & 1 & 2 & 3 & 4 & 5 & 6 & 7 & 8 & 9 & 10 & 11 \\
\hline Sex & 1.39 & 0.489 & 1 & & & & & & & & & & \\
\hline Age & 3.856 & 1.108 & $-\underset{* *}{0.277}$ & 1 & & & & & & & & & \\
\hline $\begin{array}{c}\text { Perceived } \\
\text { Compatibility }\end{array}$ & 3.009 & 0.723 & $\begin{array}{l}-0.153 \\
* *\end{array}$ & 0.117 * & 1 & & & & & & & & \\
\hline $\begin{array}{l}\text { Expectations of } \\
\text { future product } \\
\text { capabilities }\end{array}$ & 3.685 & 0.8222 & $\begin{array}{c}-0.135 \\
*\end{array}$ & -0.059 & $\begin{array}{c}-0.436 \\
* *\end{array}$ & 1 & & & & & & & \\
\hline $\begin{array}{c}\text { Perceived } \\
\text { Unavailability }\end{array}$ & 3.094 & 0.709 & 0.011 & -0.004 & -0.158 & -0.030 & 1 & & & & & & \\
\hline Perceived Risk & 3.177 & 0.616 & 0.106 & $\underset{* *}{-0.164}$ & $-\underset{* *}{0.223}$ & -0.052 & 0.533 & 1 & & & & & \\
\hline $\begin{array}{l}\text { Perceived Relative } \\
\text { Advantage }\end{array}$ & 3.533 & 0.622 & -0.085 & 0.045 & $\underset{* *}{0.683}$ & $\begin{array}{c}0.422 \\
* *\end{array}$ & -0.207 & -0.202 & 1 & & & & \\
\hline $\begin{array}{l}\text { Perceived Monetary } \\
\text { Value }\end{array}$ & 2.356 & 0.618 & $\begin{array}{c}0.168 \\
* *\end{array}$ & 0.031 & $\underset{* *}{0.277}$ & 0.058 & -0.066 & -0.079 & $\underset{* *}{0.220}$ & 1 & & & \\
\hline $\begin{array}{c}\text { Fashion } \\
\text { Innovativeness }\end{array}$ & 2.595 & 0.787 & 0.060 & 0.012 & $\underset{* *}{0.246}$ & 0.090 & -0.025 & -0.013 & 0.159 & $\begin{array}{c}0.187 \\
* *\end{array}$ & 1 & & \\
\hline $\begin{array}{l}\text { Technological } \\
\text { Innovativeness }\end{array}$ & 3.115 & 0.694 & $\underset{*}{-0.126}$ & -0.042 & $\underset{* *}{0.284}$ & $\underset{* *}{0.282}$ & 0.041 & -0.030 & $\underset{* *}{0.191}$ & 0.026 & $\underset{* *}{0.580}$ & 1 & \\
\hline $\begin{array}{l}\text { Innovation } \\
\text { Resistance }\end{array}$ & 2.601 & 0.704 & $\underset{* *}{0.168}$ & 0.048 & $\underset{* *}{-0.332}$ & -0.457 & $\begin{array}{c}0.365 \\
* *\end{array}$ & $\underset{* *}{0.492}$ & $\underset{* *}{-0.300}$ & 0.019 & -0.043 & $\begin{array}{c}-0.253 \\
* *\end{array}$ & 1 \\
\hline
\end{tabular}

$$
{ }^{*} p<0.05 ;{ }^{* *} p<0.01
$$

\subsection{Hypothesis Testing}

Multiple regression analysis was conducted to verify the effect of smart clothing properties on innovation resistance. As a result of the analysis, as shown in Table 3, the compatibility, relative advantages, and cost rationality of smart clothing did not significantly affect innovation resistance, so hypothesis 1, hypothesis 5, and hypothesis 6 were rejected. As for the perceived risk, the standardized regression coefficient was 0.219 $(p<0.001)$, and for the unavailability, the standardized regression coefficient was 0.251 $(p<0.01)$, indicating that it had a significant positive (+) effect on the innovation resistance, so hypothesis 3 and hypothesis 4 was supported. On the other hand, in the expectation of improvement, the standardized regression coefficient was $-0.403(p<0.001)$, indicating that it had a negative (-) effect on the innovation resistance, and hypothesis 2 was rejected. 
Table 3. Results of regression analysis for the relationship between innovation characteristics and innovation resistance (H1-H6).

\begin{tabular}{|c|c|c|c|c|}
\hline \multicolumn{2}{|c|}{ Variables } & $\begin{array}{l}\text { Standardized Reg. } \\
\text { Coefficient }\end{array}$ & $t$-Value & $p$-Value \\
\hline \multirow{2}{*}{$\begin{array}{c}\text { Control } \\
\text { variables }\end{array}$} & Sex & 0.106 & 2.245 & 0.025 \\
\hline & Age & 0.098 & 2.104 & 0.036 \\
\hline \multirow{6}{*}{$\begin{array}{l}\text { Independent } \\
\text { variables }\end{array}$} & Perceived Compatibility & -0.104 & -1.659 & 0.098 \\
\hline & $\begin{array}{l}\text { Expectations of future } \\
\text { product capabilities }\end{array}$ & -0.403 & -8.176 & 0.000 \\
\hline & Perceived Unavailability & 0.251 & 5.049 & 0.000 \\
\hline & Perceived Risk & 0.219 & 4.259 & 0.000 \\
\hline & $\begin{array}{l}\text { Perceived Relative } \\
\text { Advantage }\end{array}$ & 0.004 & 0.065 & 0.948 \\
\hline & Perceived Monetary Value & 0.097 & 1.945 & 0.053 \\
\hline \multicolumn{2}{|c|}{$\mathbf{R} 2$} & & 0.416 & \\
\hline \multicolumn{2}{|c|}{ Adjusted-R2 } & & 0.401 & \\
\hline \multicolumn{2}{|r|}{$\mathbf{F}$} & & $27.730^{* * *}$ & \\
\hline
\end{tabular}

The hierarchical regression method was used to verify the effect of consumers' fashion innovativeness and technological innovativeness between the attributes of smart clothing and consumer innovation resistance (Table 4). To identify the moderating effect of consumer fashion innovativeness and technological innovativeness, the first stage analysis was performed with control variables, second stage analysis with control variables and independent variables, and third stage analysis with control variables, independent variables, and moderating variables. As shown in Table 3, Hypothesis 7 was partially supported by analyzing the moderating effect of fashion innovativeness between the properties of smart clothing and innovation resistance. Consumers' fashion innovativeness did not have any effect on the relationship between compatibility, perceived risk, relative advantage, expectations of future product capabilities, and unavailability of smart clothing. However, in the relationship between cost rationality and innovation resistance of smart clothing, consumers' fashion innovativeness has a positive $(+)$ moderating effect with a standardization factor of $0.130(p<0.05)$. On the other hand, it was found that technological innovation had no effect on the relationship between the properties of smart clothing and the resistance to innovation, so hypothesis 8 was rejected.

Table 4. Results of hierarchical regression analysis on the moderating effect of consumer characteristics for the relationship between innovation characteristics and innovation resistance $(\mathrm{H} 7-\mathrm{H} 8)$.

\begin{tabular}{|c|c|c|c|c|}
\hline & Variables & Model 1 & Model 2 & Model 3 \\
\hline \multirow{2}{*}{ Control Variables } & Sex & $0.211^{* * *}$ & 0.078 & 0.079 \\
\hline & Age & 0.094 & 0.082 & $0.068^{*}$ \\
\hline \multirow{8}{*}{ Independent Variables } & Perceived Compatibility & & -0.090 & -0.117 \\
\hline & $\begin{array}{l}\text { Expectations of Future Product } \\
\text { Capabilities }\end{array}$ & & $-0.363^{* * *}$ & $-0.341^{* * *}$ \\
\hline & Perceived Unavailability & & $0.265^{* * *}$ & $0.244^{* * *}$ \\
\hline & Perceived Risk & & $0.219^{* * *}$ & $0.189 * * *$ \\
\hline & Relative Advantage & & 0.005 & 0.007 \\
\hline & Perceived Monetary Value & & 0.076 & 0.044 \\
\hline & Fashion Innovativeness (A) & & 0.109 * & 0.114 * \\
\hline & Technological Innovativeness (B) & & $-0.208^{* * *}$ & $-0.178^{* *}$ \\
\hline
\end{tabular}


Table 4. Cont.

\begin{tabular}{|c|c|c|c|c|}
\hline & Variables & Model 1 & Model 2 & Model 3 \\
\hline \multirow{15}{*}{ Interaction } & Perceive & & & 0.107 \\
\hline & $\begin{array}{r}\text { Expectat } \\
\mathrm{C}\end{array}$ & & & -0.075 \\
\hline & Perceive & & & 0.034 \\
\hline & Per & & & -0.004 \\
\hline & Relati & & & -0.139 \\
\hline & Perceivec & & & 0.130 * \\
\hline & Perceive & & & -0.128 \\
\hline & $\begin{array}{r}\text { Expectat } \\
\mathrm{C}\end{array}$ & & & -0.009 \\
\hline & Perceive & & & -0.090 \\
\hline & Per & & & 0.040 \\
\hline & Relati & & & 0.057 \\
\hline & Perceive & & & 0.065 \\
\hline & $\mathrm{R}^{2}$ & 0.042 & 0.441 & 0.489 \\
\hline & Adjusted-R ${ }^{2}$ & 0.036 & 0.423 & 0.451 \\
\hline & F & $6.949 * *$ & $24.424^{* * *}$ & $12.906^{* * *}$ \\
\hline
\end{tabular}

\section{Discussion and Implications}

This study examined the impact of innovative characteristics of smart clothing with regard to innovation resistance to smart clothing, including the unavailability and cost rationality of smart clothing, to determine why smart clothing is slow to spread despite positive prospects of various institutions. The analysis shows that the unavailability and perceived risk of smart clothing had a positive impact on innovation resistance, but the expectation of improvement on innovation had a negative impact on innovation resistance. In other words, consumers resist smart clothing when they think smart clothing is dangerous or cannot be used when they want to. This supports the results of a prior study [26] that smart clothes are less available than other wearable devices due to the nature of clothes such as laundry and seasonality and are not well accepted by consumers. Meanwhile, expectations that products with improved performance and stability will be released in the future have lowered resistance to smart clothing. This is different from a prior study, in which consumers are hesitant to accept products at the present time as they expect better new products to emerge in the near future study $[55,60]$. Rather, the results of this study suggest that interest and favorable attitudes toward specific technologies, products, and functions have a positive impact on consumer acceptance.

On the other hand, consumers' innovativeness has been shown to function as a moderator in the relationship between innovative characteristics of smart clothing and innovation resistance. First, it has been shown that consumers' fashion innovativeness has a moderating effect on the relationship between cost rationality and innovation resistance. In other words, consumers' fashion innovativeness plays a role in strengthening innovation resistance to affordable smart clothing, which can be inferred to be burdensome to purchase relatively expensive smart clothing [26] as the trend changes. However, consumer technological innovativeness has not had any moderating effect on the relationship between smart clothing and innovation resistance. This is different from Park and Noh [54], who state that consumer technological innovativeness affects the acceptance and purchase of smart clothing. This seems to be because consumers perceive smart clothing as clothing rather than wearable devices, and consumers who are highly innovative in technology 
prefer to purchase the latest devices rather than smart clothes [61]. Considering the results of the existing research and the results of this study, further research is expected to be needed to analyze the moderating effects of consumer innovation. Summing up the results of this study, it is necessary to reduce the perceived risk and increase the availability of smart clothing by releasing products that are safe to wear for a long time and improve performance, durability, and availability.

Despite the implications discussed above, this study had limitations in that it failed to identify and validate the relationship between smart clothing with specific features and innovation resistance. If research is conducted on smart clothing with various other attributes that have been actually released or are scheduled to be released in the future, it will be able to derive important practical implications and academic implications. For example, if a study on the overall perception and attitude of consumers on smart protective clothing and healthcare smart textiles, which will become major products in the smart clothing market in the future, and the impact of consumer's healthcare innovativeness and safety innovativeness in the process of smart clothing resistance, would be conducted, $t$ is expected to contribute to the acceptance and spread of smart clothing.

Author Contributions: N.J. designed the study and developed the theoretical framework, besides analyzing data, and drafted the manuscript. K.-H.L. guided the development of the theoretical framework, results, and conclusion and reviewed the manuscript. All authors have read and agreed to the published version of the manuscript.

Funding: This work was supported by the Ministry of Education of the Republic of Korea and the National Research Foundation of Korea (NRF-2017S1A5A2A01026763).

Institutional Review Board Statement: This study was met the Bioethics and Safety Act's deliberation exemption requirements and approved by Hanyang University Institutional Review Board ((HYU-2019-01-035, 28 February 2019).

Informed Consent Statement: Informed consent was obtained from all subjects involved in the study.

Data Availability Statement: The data will be made available on request from the corresponding author.

Conflicts of Interest: The authors declare no conflict of interest.

\section{References}

1. Garter. Gartner Says Worldwide Wearable Device Sales to Grow 26 Percent in 2019. Available online: https:/ /www.gartner.com/en/ newsroom/press-releases/2018-11-29-gartner-says-worldwide-wearable-device-sales-to-grow- (accessed on 16 December 2020).

2. Kozlova, A. Wearables Classification by Teslasuit Team. Available online: https://teslasuit.io/blog/wearables/detailedwearables-classification-by-teslasuit-team (accessed on 2 January 2021).

3. Kwon, H.Y.U.S. Smart Clothing Energizes Wearable Market. Available online: http://news.kotra.or.kr/user/globalAllBbs/ kotranews / album/2/globalBbsDataAllView.do?dataIdx=160864\&column (accessed on 22 November 2020).

4. Park, H. New Growth Strategy of Fashion Clothing Industry through Fashion Design and ICT Convergence Invigoration. Available online: https://library.kiet.re.kr/CORE/?moduleName=_core.KrmsSearchDetail\&control_no=39404 (accessed on 1 June 2020).

5. Ju, N.; Lee, K.H. Consumer resistance to innovation: Smart clothing. Fash. Text. 2020, 7, 1-19. [CrossRef]

6. Cientifica. Smart Textiles and Wearables-Markets, Applications and Technologies; Cientifica Ltd.: Birmingham, UK, 2016.

7. Choi, J.W.U.S. Wearable Market Trends. Available online: http://news.kotra.or.kr/user/globalAllBbs/kotranews/album/ 781/globalBbsDataAllView.do?dataIdx=163102\&column=title\&search=\%EC \%9B \%A8\%EC\%96\%B4\%EB \%9F\%AC \%EB\% B8\%94\&searchAreaCd=\&searchNationCd=\&searchTradeCd=\&searchStartDate=\&searchEndDate=\&searchCategoryIdxs $=$ \&searchIndustryCateId $x=\&$ page $=2 \&$ row $=10$ (accessed on 15 June 2020).

8. Tsui, J. The Relationship between Consumers, Wearable Technology and Fashion Brands. Available online: http://www. lightspeedresearch.com/newsletter-q3-2015/relationship-consumers-wearable-technology-fashion-brands / (accessed on 11 May 2020).

9. Apparel Industry Has Opportunity to Boost Awareness of Smart Fabrics, Reports. Available online: https://www.npd.com/wps/ portal/npd/us/news / press-releases/2015/apparel-industry-has-opportunity-to-boost-awareness-of-smart-fabrics-reportsnpd/ (accessed on 11 May 2020).

10. Kim, H.J. Wear smart clothing in the smart age. TTA J. 2011, 137, 18-19.

11. Gourville, J.T. Eager sellers and stony buyers: Understanding the psychology of new-product adoption. Harv. Bus. Rev. 2006, 84, 98-106. 
12. Diamond, M.A. Resistance to change: A psychoanalytic critique of Argyris and Schon's contributions to organization theory and intervention. J. Manag. Stud. 1986 23, 543-562. [CrossRef]

13. Ellen, P.S.; Bearden, W.O.; Sharma, S. Resistance to technological innovations: An examination of the role of self-efficacy and performance satisfaction. J. Acad. Mark. Sci. 1991, 19, 297-307. [CrossRef]

14. Ram, S. A model of innovation resistance. ACR North Am. Adv. 1987, 14, 208-212.

15. Szmigin, I.; Foxall, G. Three forms of innovation resistance: The case of retail payment methods. Technovation 1998, 18, $459-468$. [CrossRef]

16. Murdock, G.W. Resistance to Innovation; Overcoming the Consumer Research Bias Toward Innovators. In Proceedings of the AMA Educator's Proceedings, New Orleans, Louisiana, 31 March-2 April 1990; pp. 68-73.

17. Zaltman, G.; Wallendorf, M. Consumer Behavior, Basic Findings and Management Implications; John Wiley \& Sons: New York, NY, USA, 1979.

18. Ryu, Y.J. Consumers' innovation resistance scale development, Korean J. Consum. Adv. Psychol. 2011 12, $191-216$.

19. Kelly, P.; Kranzberg, M. Technological Innovation: A Critical Review of Current Knowledge; San Francisco Press: San Francisco, CA, USA, 1978.

20. Sheth, J.N. Psychology of innovation resistance: The less developed concept (LDC) in diffusion research. Res. Mark. 1981, 4, 273-282.

21. Robertson, T.S. Innovative Behavior and Communication; Rinehart \& Winston: New York, NY, USA, 1971.

22. Tormatzky, L.; Klein, K. Innovation characteristics and innovation adoption implementation: A meta-analysis of findings. IEEE Trans. Eng. Manag. 1982, 29, 28-45. [CrossRef]

23. Rogers, E.M. Diffusion of Innovations, 5th ed.; Free Press: New York, NY, USA, 2003.

24. Nam, C.; Lee, Y.-A. Validation of the wearable acceptability range scale for smart apparel. Fash. Text. 2020, 7, 1-17. [CrossRef]

25. Cho, H.; Kim, J.; Lee, J. A study of directions for development of smart clothing based on the consumer's lifestyle. Sci. Emot. Sensib. 2010, 13, 11-20.

26. Ju, N. Consumer Resistance to Innovation: Focused on Smart Clothing. Unpublished. Ph.D. Thesis, Hanyang University, Seoul, Korea, 22 February 2018.

27. Aaker, D.A.; Keller, K.L. Consumer evaluations of brand extension. J. Mark. 1990, 54, 27-41. [CrossRef]

28. Hartman, C.L.; Price, L.L.; Duncan, C.P. Consumer evaluation of franchise extension products: A categorization processing perspective. Adv. Consum. Res. 1990, 17, 120-126.

29. Ma, Y.-S.; Won, D.; Park, S. Moderating effect of consumer innovativeness on relationship between sportwearable device's innovation attribute and innovation resistance of college students. Korean J. Sport Sci. 2015, 26, 861-873.

30. Dhebar, A. Speeding high-tech producers, meet the balking consumer. MIT Sloan Manag. Rev. 1995, 37, 37-54.

31. Cheon, S.J. Present State of 'IoT Wearable Device' Viewed from Silicon Valley. Available online: https://news.kotra.or.kr/user/ globalBbs $/$ kotranews $/ 4$ /globalBbsDataView.do?setIdx=243\&dataIdx=151681 (accessed on 2 September 2020).

32. Hiltunen, M.; Laukka, M.; Luomala, J. Mobile User Experience; Hanbit Media: Seoul, Korea, 2002.

33. Ryu, J.H.; Moon, H.Y.; Choi, J. Analysis of influence factors on the intention to use personal cloud computing. J. Inf. Technol. Svcs. 2013, 12, 319-335. [CrossRef]

34. Jacoby, J.; Kaplan, L.B. The components of perceived risk. In Proceedings of the Third Annual Conference of the Association for Consumer Research, Chicago, IL, USA, 3-5 November 1972; pp. 382-393.

35. Sheehy, H. Consumers Biotechnology: A Synopsis of Survey and Focus Group Research. Biotechnology and the Consumer; Knoppers, B.M., Mathios, A.D., Eds.; Springer: Boston, MA, USA, 1998. [CrossRef]

36. Ram, S.; Sheth, J.N. Consumer resistance to innovations: The marketing problem and its solutions. J. Consum. Mark. 1989, 6, 5-14. [CrossRef]

37. Bredahl, L. Determinants of consumer attitudes and purchase intentions with regard to genetically modified foods-Results of a cross-national survey. J. Consum. Policy 2001, 24, 23-61. [CrossRef]

38. Saba, A.; Rosati, S.; Vassallo, M. Biotechnology in agriculture: Perceived risk, benefits and attitudes in Italy. Br. Food J. 2000, 102, 114-122. [CrossRef]

39. Woodside, A.G.; Biemans, W.G. Modeling innovation, manufacturing, diffusion and adoption/rejection processes. J. Bus. Ind. Mark. 2005, 20, 380-393. [CrossRef]

40. Shiffman, L.G.; Kanuk, L.L. Consumer Behavior; Prentice-Hall: Englewood Cliffs, NC, USA, 1991.

41. Davis, F.D. Perceived usefulness, ease of use, and the user acceptance of information technology. MIS Q. 1989, 13, 318-339. [CrossRef]

42. Kang, K.Y.; Jin, H.J. A study on consumers' clothing buying intention adopted by the technology acceptance model. J. Korean Soc. Cloth. Text. 2007, 31, 1211-1221. [CrossRef]

43. Noh, M.J.; Park, H.H. Acceptance of the smart clothing according to trend and information innovation. J. Korea Content Assoc. 2011, 11, 350-363. [CrossRef]

44. Chae, J.M.; Cho, H.S.; Lee, J.H. A study on consumer acceptance toward the commercialized smart clothing. Korean J. Sci. Emot. Sensib. 2009, 12, 181-192.

45. Morgan Stanley. Wearable Devices. Available online: http://byinnovation.eu/wp-content/uploads/2014/11/MORGANSTANLEY-BLUE-PAPER_Internet-of-Things.pdf (accessed on 18 September 2020). 
46. Shin, Y.M.; Lee, S.C.; Lee, H.G. System characteristics, user perceptions in the prediction of mobile internet usage: A re-examination of the technology acceptance model. Korean Manage. Rev. 2004, 33, 1283-1310.

47. Dodds, W.B.; Monroe, K.B.; Grewal, D. Effects of price, brand, and store information on buyers' product evaluations. J. Mark. Res. 1991, 28, 307-319. [CrossRef]

48. Garbarino, E.C.; Edell, J.A. Cognitive effort, affect, and choice. J. Consum Res. 1997, 24, 147-158. [CrossRef]

49. Foxall, G.R. Marketing new technology: Markets, hierarchies, and user-initiated innovation. Manag. Decis. Econ. 1988, 9, 237-250. [CrossRef]

50. Midgley, D.F.; Dowling, G.R. Innovativeness: The concept and its measurement. J. Consum. Res. 1978, 4, 229-242. [CrossRef]

51. Goldsmith, R.E.; Hofacker, C.F. Measuring consumer innovativeness. J. Acad. Mark. Sci. 1991, 19, 209-221. [CrossRef]

52. Tigert, D.J.; Ring, L.J.; King, C.W. Fashion involvement and buying behavior: A methodological study. Adv. Consum. Res. 1976, 3, 46-52.

53. Agarwal, R.; Prasad, J. Are individual differences germane to the acceptance of new information technologies? Decis. Sci. 1999, 30, 361-391. [CrossRef]

54. Park, H.-H.; Noh, M.J. The Influence of innovativeness and price sensitivity on purchase intention of smart wear. J. Korean Soc. Cloth. Text. 2012, 36, 218-230. [CrossRef]

55. Holak, S.L.; Lehmann, D.R.; Sultan, F. The role of expectations in the adoption of innovative consumer durables: Some preliminary evidence. J. Retail. 1987, 63, 243-259.

56. Yoo, P.H.; Lee, S.H. A study on the innovation resistance of consumers in adoption process of new product: Concentrated on innovation resistance model. Korean Acad. Soc. Bus. Adm. 1994, 23, 217-250.

57. Jo, I.-J.; Kim, S.-K.; Yang, S.-B. A study on influencing factors on user's adoption resistance to personal cloud computing service. Knowl Manag. Res. 2015, 16, 117-142. [CrossRef]

58. Voss, G.B.; Parasuraman, A.; Grewal, D. The roles of price, performance, and expectations in determining satisfaction in service exchanges. J. Mark. 1998, 62, 41-61. [CrossRef]

59. Kim, H.; Rhee, E.-Y. Consumer segmentation of clothing products by fashion conformity/innovativeness and their reference groups. J. Korean Soc. Cloth. Text. 2001, 25, 1341-1352.

60. Dhebar, A. Information technology and product policy: 'Smart' products. EMJ 1996, 14, 477-485. [CrossRef]

61. Lee, K.-H.; Ju, N. Diffusion or confusion of innovation. Res. J. Costumec. 2018, 26, 155-171. [CrossRef] 